\title{
Distribution and Abundance of the Central American River Turtle, Dermatemys Mawii, in Southern Quintana Roo, Mexico: Implications for a Regional Conservation Strategy
}

Calderón-Mandujano RR ${ }^{1}$, Hernández-Arana HA ${ }^{1 *}$ and Flores-Villela $\mathbf{O A}^{2}$

${ }^{1}$ The Southern Border College, Chetumal Unit, Centenario Avenue Km 5.5, CP 77014, Chetumal, Quintana Roo, Mexico ${ }^{2}$ UNAM. Av. Universidad 3000, Circuito Exterior S / N. Delegation Coyoacán, CP 04510, Ciudad Universitaria, DF, Mexico

\begin{abstract}
We estimated the distribution and abundance of the Central American River Turtle, Dermatemys mawii, in four aquatic systems in southern Quintana Roo, Mexico. Using nets and free diving we captured 52 individuals $D$. mawii among the winter, dry and rainy seasons. We recorded 12 variables to characterize the habitat and correlated these with the abundance of $D$. mawii. Using catching per unit effort, we evaluated the species' relative abundance for each aquatic system. Using Maxent, we modeled the potential distribution of $D$. mawii using historical and present locality data. We recorded 81 D. mawii individuals using systematic sampling and casual observations. La Union was the site with the highest relative abundance ( $\sim$ ind.-net). We found a negative correlation between $D$. mawii abundance and salinity. The model of potential distribution identified sites with ecological conditions suitable for the species where it is undocumented. Information about the ecology of this species remains scarce, but we propose that identifying management units could improve conservation of the species at local and regional levels.
\end{abstract}

Keywords: Turtles; Southern Mexico; Critically endangered

\section{Introduction}

The Central American River Turtle, Dermatemys mawii Gray, 1847 is one of the 25 most endangered species of turtles in the world [1]. It is the largest freshwater turtle in Mexico, distributed in the states of Veracruz, Chiapas, Oaxaca, Tabasco, Campeche and Quintana Roo; it is also found in northern Guatemala and Belize [2,3]. In the past few decades, some populations have decline or become extinct [3-9]. The primary threats to the species' survival are over-exploitation $[4,6,10$ $12]$ and habitat loss or habitat perturbation $[5,13,14]$. However, life history characteristics such as the species' low reproductive rate and low genetic variability accentuate its imperilment $[3,9,15]$.

Despite the critical situation facing by D. mawii, there is insufficient information to design and support species-specific monitoring and conservation programs in the wild [3]. This is particularly true for southern Quintana Roo, Mexico, where D. mawii is used traditionally as a food resource [16]. The historic distribution of the species in this area is limited to several isolated sites in or near the Rio Hondo (natural frontier between Mexico and Belize), that mainly correspond to freshwater bodies in Belize $[2,3,6,8,10,12,17,18]$. In regard to this situation, the objectives of the work reported herein were to confirm the presence of D. mawii in this portion of the Rio Hondo, estimate relative abundance, and model the potential distribution of the species in southern Quintana Roo, Mexico.

\section{Materials and Methods}

The study area is located in southern Quintana Roo and belongs to the Rio Escondido hydrologic Basin. This basin lies within the hydrologic region number 33, east Yucatan, located in the states of Campeche and Quintana Roo [19]. In the northeastern portion of the Basin, we collected data from creeks or channels at three localities: northern Chetumal Bay (CNCB), Laguna Guerrero (LG), and Laguna Chile Verde (LCV). In the southwestern portion of the basin, we collected data from three localities along the Rio Hondo: Obregon Viejo (OV), Cacao (C), and La Union (LU). The channels, as well as the lagoons and the Rio Hondo, flow into Chetumal Bay
(Figure 1). Chetumal Bay maintains an average salinity of 8 to 18 ups [20], while the northern sites maintain an average salinity of $4.3 \pm$ 0.7 ups, and those from the southwestern portion (Rio Hondo) have an even lower salinity ( $0.711 \pm 0.066$ ups) (Calderón-Mandujano $\mathrm{R}$ unpublished data). The creeks as well as Laguna Guerrero and Laguna Chile Verde are systems with crystalline waters with an average depth of four meters. Rio Hondo has a depth of $10 \mathrm{~m}$, and is $50 \mathrm{~m}$ wide and $120 \mathrm{~km}$ long, with several tributaries [21]. Due to the rugged terrain, there is a higher slope and the speed of the stream reduces the flow of salt water from the Bay inside the river. The vegetation type that dominates both systems is mangrove, but tropical deciduous forest and lower seasonal evergreen forest are also present [22].

\section{Historic and current distribution}

We reviewed the literature to assemble all historic distribution records for D. mawii from southern Quintana Roo and nearby areas of Belize [10]. These records were projected on a basic map that also includes locality data obtained during the present study (Figure 1).

To evaluate the current distribution of $D$. mawii, we used information obtained from interviews with fishermen and inhabitants of ten communal lands, closer to the water bodies in the zone [16]. Additionally, we used the data from sites where individuals were incidentally recorded during the course of this study.

*Corresponding author: Hernández-Arana HA, The Southern Border College, Chetumal Unit, Centenario Avenue Km 5.5, CP 77014, Chetumal, Quintana Roo, Mexico, Tel: +52 983835 0440; E-mail: hernand@ecosur.mx, r21e73@yahoo.com

Received September 04, 2017; Accepted September 18, 2017; Published September 25, 2017

Citation: Calderón-Mandujano RR, Hernández-Arana HA, Flores-Villela OA (2017) Distribution and Abundance of the Central American River Turtle, Dermatemys Mawii, in Southern Quintana Roo, Mexico: Implications for a Regional Conservation Strategy. J Biodivers Endanger Species 5: 198. doi: 10.4172/2332-2543.1000198

Copyright: ( 2017 Calderón-Mandujano RR, et al. This is an open-access article distributed under the terms of the Creative Commons Attribution License, which permits unrestricted use, distribution, and reproduction in any medium, provided the original author and source are credited. 

Dermatemys Mawii, in Southern Quintana Roo, Mexico: Implications for a Regional Conservation Strategy. J Biodivers Endanger Species 5: 198. doi: 10.4172/2332-2543.1000198

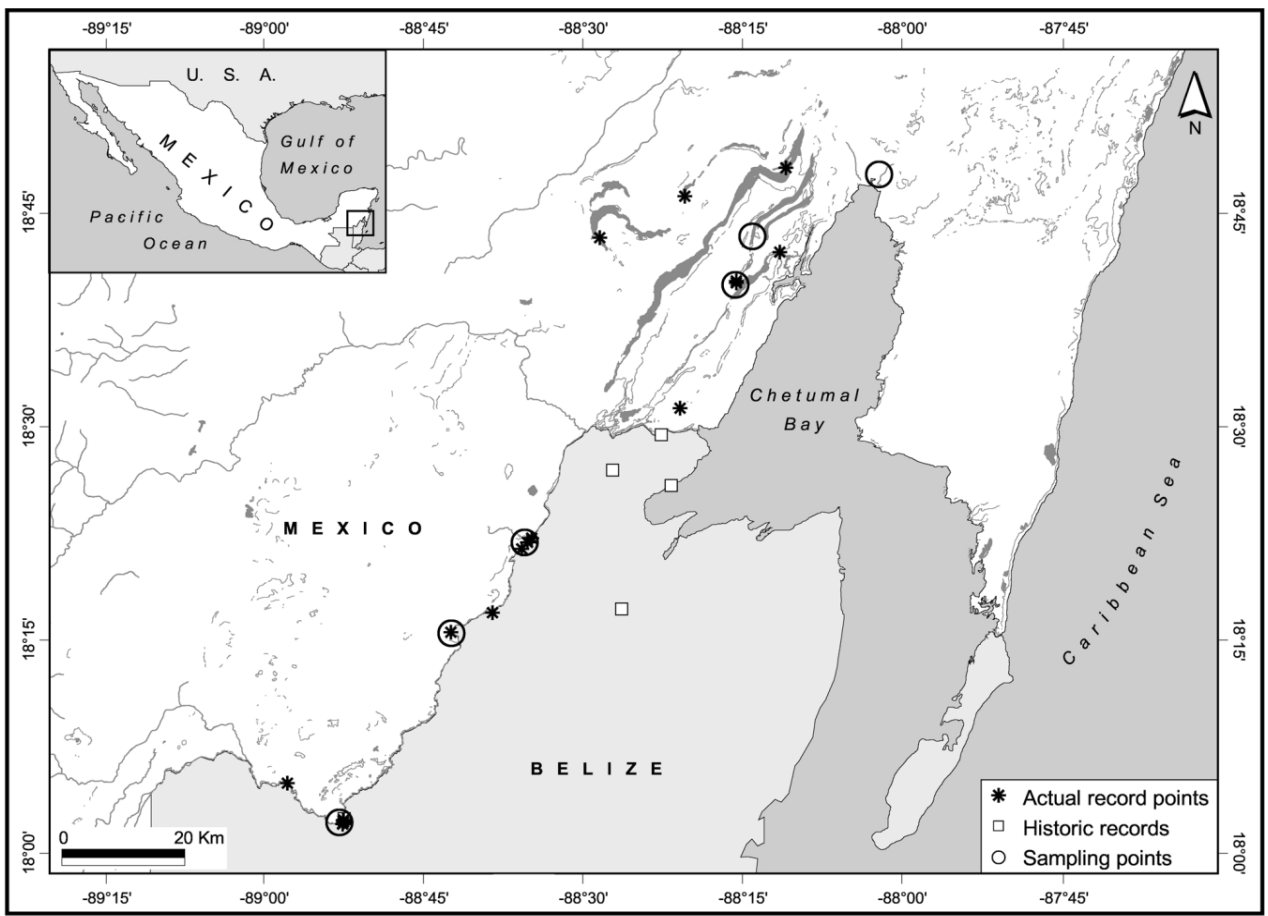

Figure 1: Study area in southwestern Quintana Roo showing sampling sites, historic records \& records obtained during this study.

\section{Relative abundance}

We sampled our six chosen study sites on 25 separate field trips: seven field trips from February to May 2009, with incidental observations to verify that the information from fishermen and inhabitants was correct [16]; and 18 field trips between January and August 2010 with systematic sampling. For these last 18 field trips, we sampled across the three prevailing climatic seasons (winter from October to January, dry season from February to June and rainy season from July to September), conducting a field trip to each site for each climate season. The fieldwork was done using nets and direct search by free diving that were the most appropriate methods according with the interviews [16]. At each site, we placed three nets perpendicular to the riverbank, with a separation distance between nets of at least $500 \mathrm{~m}$. The nets were made by fishermen of turtles with nylon omega thread with a mesh opening of $12 \mathrm{~cm}$, a length of 50 meters and seven meters high. The nets were checked every four to six hours for three consecutive days and two nights, for a total of 48 hours of sampling per net, site and season. In total, this sums to $3456 \mathrm{hrs}-$ net. Free diving was done from 10:00 am to $12: 00 \mathrm{pm}$ and 03:00 pm to 05:00 pm away the net sites. Free diving was realized from one to five $\mathrm{km}$ away the nets to avoid interference between the two sampling methods. Total free diving effort summed 600 hours. Simultaneously, we implemented a capture-mark-recapture program to estimate D. mawii population size. To mark the turtles, we used a combination of PIT tags and an externally visible numerical tag made of soft plastic (piece of garden hose) and attached with plastic strings to the carapace edge (previously perforated with two holes to insert the strings)

We analyzed these data using the Cormack-Jolly-Seber stochastic method, as modified by Pledger and Efford [23]. This method is based on the assumption of capture-recapture methods. It uses the inverse modeling of Carothers to reduce the bias generated in the estimation of the population due to the variation of the probability in the catches in unstable populations. As it is the case for species subjected to exploitation. At the time of capture, we recorded certain environmental variables that influence the distribution of $D$. mawii according to Ureña-Arana [24] and Zenteno-Ruiz et al. [25]; habitats with greater availability of shelters and resources as well as high depth and riparian vegetation are the most likely to harbor the species. We also recorded additional variables identified by the fishermen we interviewed as being important to the species. The recorded variables were salinity, transparency, total suspended solids, temperature, conductivity, depth, slope, vegetation cover on the riverbank and bottom, number of shelters, distance to the nearest village, and distance to the Chetumal Bay.

We measured relative abundance of $D$. mawii across sites by comparing the number of captures per unit effort [25]. We evaluated the relationships between the environmental variables and $D$. mawii abundance using Pearson' correlation coefficient $(\alpha=0.05)$ [26]. We used Statistica v. 7 [27] for all analyses. All captured D. mawii were liberated at the sampling sites after being measured and sexed $[6,17]$.

\section{Potential distribution}

We modeled the potential distribution of $D$. mawii using maximum entropy (Maxent) [28]. It allows estimating the probability of occurrence of one species from minimizing the relative entropy between the probability densities obtained from the data of occurrence of the species on one hand, and from the landscape variables on the other [29]. This method also allows analyzing continuous or categorical variables, with relatively few records, as is the case for the species [30]. All the points obtained during sampling $(n=18)$ were used in the model, as well as the points representing incidental observations during the study $(n=7)$ (captures by fishermen, or isolated records or outside the sampling sites), totalizing 25 sites. The environmental variables used were six thematic maps (water bodies, temperature, actual ecologic 
Citation: Calderón-Mandujano RR, Hernández-Arana HA, Flores-Villela OA (2017) Distribution and Abundance of the Central American River Turtle, Dermatemys Mawii, in Southern Quintana Roo, Mexico: Implications for a Regional Conservation Strategy. J Biodivers Endanger Species 5: 198. doi: 10.4172/2332-2543.1000198

Page 3 of 6

systems- vegetation, soils, geology, bulk flow of waters), from the Plan Ecorregional de las Selvas Maya, Zoque y Olmeca [31]. These maps offer most of the available information for the habitat requirements of the species according to the variables and the scale analyzed.

We used predetermined parameters in the program, and reiterated the analysis 500 times in the latest Maxent 2.1 version. The most important variables were estimated using a Jackknife test that allowed us to obtain a potential distribution map with less uncertainty. Finally, we repeated the modeling to obtain a map with the highest probabilities of occurrence for the species.

\section{Results}

\section{Historic and present distribution}

Historically, only two documented records are available for the Mexican side of the study site: one for Laguna Guerrero [32] and another for Lagunitas [33], close to La Union Village in the Rio Hondo. Dermatemys mawii has been recorded in nearby portions of Belize (Figure 1) $[2,8,10,12,17,34,35]$.

The exploratory samples confirmed the presence of $D$. mawii in four of the six sites we sampled: three from Rio Hondo (OV, C, LU) and one in the northeast of the Basin (LG). With these points and those additionally obtained during the study, the presence of the species was recorded in two new water bodies, which slightly expand the species' distribution to the north (Table 1, Figure 1).

\section{Relative abundance}

The 25 field trips yielded 81 records for D. mawii. In 2009, 14 records were obtained: nine in February, one in April and four in May; they were originated from incidental observations. In 2010, 67 records were obtained through systematic sampling from the Rio Hondo (Table 2). In this area, the average relative abundance was 1.74 turtles per net; with 0.33 turtles per net (OV), 0.75 turtles per net (C), and 3.67 turtles per net (LU). No records of $D$. mawii were obtained at the sites in the northeast portion of the Basin (CNBC, LG y LCV).

Only three of the captured specimens were recaptured, two males adults and one immature female (Table 2), and for that reason we could not apply the model to estimate the population size. All recaptures were in the same site of capture. The relative abundances showed a negative correlation with salinity $(r=-0.6423 ; p<0.05)$, and did not show statistically significant correlation with any of the other measured environmental variables.

Of the 67 D. mawii sightings recorded during the systematic sampling, 52 involved capture of the turtle and 15 were only observed. Of these, $73.1 \%(n=49)$ were adults, while the remaining $26.9 \%(n=18)$ were immature and lacked developed sexual characters to differentiate

\begin{tabular}{|c|c|c|c|}
\hline \multirow{2}{*}{ Locality } & \multicolumn{2}{|c|}{ Geographic coordinates } & $\begin{array}{c}\text { No. of } \\
\text { individuals }\end{array}$ \\
\cline { 2 - 3 } & Latitude & Longitude & 5 \\
\hline Laguna de Bacalar & $16^{\circ} 52^{\prime} 47.79^{\prime \prime}$ & $88^{\circ} 11^{\prime} 2.87^{\prime \prime}$ & 5 \\
\hline Laguna Guerrero & $18^{\circ} 42^{\prime} 28.31^{\prime \prime}$ & $88^{\circ} 15^{\prime} 36.81^{\prime \prime}$ & 1 \\
\hline Boca de la Barra & $18^{\circ} 45^{\prime} 13.89^{\prime \prime}$ & $88^{\circ} 11^{\prime} 34.56^{\prime \prime}$ & 1 \\
\hline Raudales-Chile Verde & $18^{\circ} 42^{\prime} 37.41^{\prime \prime}$ & $88^{\circ} 15^{\prime} 36.81^{\prime \prime}$ & 2 \\
\hline Sabana en Chetumal & $18^{\circ} 31^{\prime} 12.82^{\prime \prime}$ & $88^{\circ} 20^{\prime} 42.75^{\prime \prime}$ & 1 \\
\hline Laguna San Felipe-Bacalar & $18^{\circ} 46^{\prime} 25.28^{\prime \prime}$ & $88^{\circ} 28^{\prime} 17^{\prime \prime}$ & 3 \\
\hline Laguna Negra & $18^{\circ} 50^{\prime} 12.59^{\prime \prime}$ & $88^{\circ} 25.82^{\circ} 20^{\prime}$ & 1 \\
\hline
\end{tabular}

Table 1: Records of for Dermatemys mawii outside the sampling sites and number of individuals recorded for each site.

\begin{tabular}{|c|c|c|c|c|c|c|c|c|c|c|}
\hline \multirow{2}{*}{ Locality } & \multicolumn{3}{|c|}{$\begin{array}{c}\text { Rainy } \\
\text { Season }\end{array}$} & \multicolumn{3}{c|}{ Winter } & \multicolumn{3}{c|}{ Dry Season } & \multirow{2}{*}{ Total } \\
\cline { 2 - 10 } & F & M & NR & F & M & NR & F & M & NR & \\
\hline CNBC & 0 & 0 & 0 & 0 & 0 & 0 & 0 & 0 & 0 & 0 \\
\hline LCV & 0 & 0 & 0 & 0 & 0 & 0 & 0 & 0 & 0 & 0 \\
\hline LG & 0 & 0 & 0 & 0 & 0 & 0 & 0 & 0 & 0 & 0 \\
\hline OV & 0 & 0 & 0 & 1 & 1 & 0 & 0 & $2\left(1^{\text {b }}\right)$ & 0 & $4(1)$ \\
\hline C & 2 & 0 & 0 & 0 & 1 & 3 & 2 & 0 & 1 & 9 \\
\hline LU & 6 & 2 & 5 & $11\left(1^{\text {a }}\right)$ & 4 & 4 & 13 & $4\left(1^{\text {c }}\right)$ & 5 & $54(2)$ \\
\hline Total & 8 & 2 & 5 & $12(1)$ & 6 & 7 & 15 & $6(2)$ & 6 & $67(3)$ \\
\hline
\end{tabular}

a:marked 255 days ago ; ${ }^{b}$ :marked 103 days ago ; c:marked 32 days ago.

Table 2: Captures and recaptures of Dermatemys mawii for each climate season during the systematic sampling at six sampling sites: channels northern of Chetumal Bay (CNCB), Laguna Chile Verde (LCV), Laguna Guerrero (LG), Obregón Viejo (OV), Cacao (C) y La Unión (LU), for three sex categories, F: female, M: male, NR: not recorded. Recaptures are between parentheses.

them. Among the adults, $71.4 \%(n=35)$ were females and $28.6 \%(n=14)$ were males. Females were more frequently captured during the dry season (Table 2). The average length for the carapace was $305 \pm 57 \mathrm{~mm}$. Three categories can be established based on body sizes found: 10-22 $\mathrm{cm}, 24-38 \mathrm{~cm}$ y $40-48 \mathrm{~cm}$ [9]. In our case, the vast majority (95\%) of the turtles captured fell into a size class from 26 to $40 \mathrm{~cm}$; individuals larger than $40 \mathrm{~cm}$ were not encountered. The sizes for the immatures were $23.1 \pm 4.1 \mathrm{~cm}$. The average body mass was $4,018 \pm 1,922 \mathrm{~g}$. Males averaged larger $(35.6 \pm 3.3 \mathrm{~cm})$ than females $(29.5 \pm 5.0 \mathrm{~cm})$.

\section{Potential distribution}

The ecological niche models obtained using Maxent, suggest that the geographic distribution of ecological conditions suitable for $D$. mawii life, are broader than currently described in the literature and found in this study. According to these models, some water bodies, which extend slightly to the north, may be suitable for $D$. mawii. The models suggest that the presence of water bodies (35\%), the soil type (32.4\%), temperature $(20.3 \%)$, geomorphology $(7.5 \%)$ and rainfall (4\%) are necessary for the occurrence of the species. The confidence threshold was estimated in 0.318 , and because of this, the final map only shows values higher than that probability (Figure 2) [28].

\section{Discussion}

This study confirms the presence of Dermatemys mawii in southeastern Quintana Roo [3,33]. Moreover, it is the first work that shows that the species has populations in this zone, surpassing recent data obtained from Belize and other areas in southern Mexico $[3,5,7,8]$.

This lack of information is not an exclusive problem for the species, but is a recurrent problem among reptiles and this is due to the lack of specific studies in general [36]. This suggests that despite its prolonged use as a source of food for centuries [37,38], this species has been understudied. Notwithstanding the geographic proximity of the studies done in Belize up to date and as a result of the present work [16], Rio Hondo has started to be considered as a priority site for the conservation of the species [8].

Some places like La Union, in the high part of Rio Hondo, showed a higher relative abundance to those recently registered in Tabasco [25] and Belize [8], where the species populations tend to decrease $[6,10,11]$. We know that in southeast Quintana Roo, the species has remained relatively abundant in some places, despite being under clandestine exploitation for commerce and personal consumption $[3,16]$; but this does not exclude the risk of extinction of some populations in the area, as it has been documented in other localities along the species distribution $[5,12]$. 


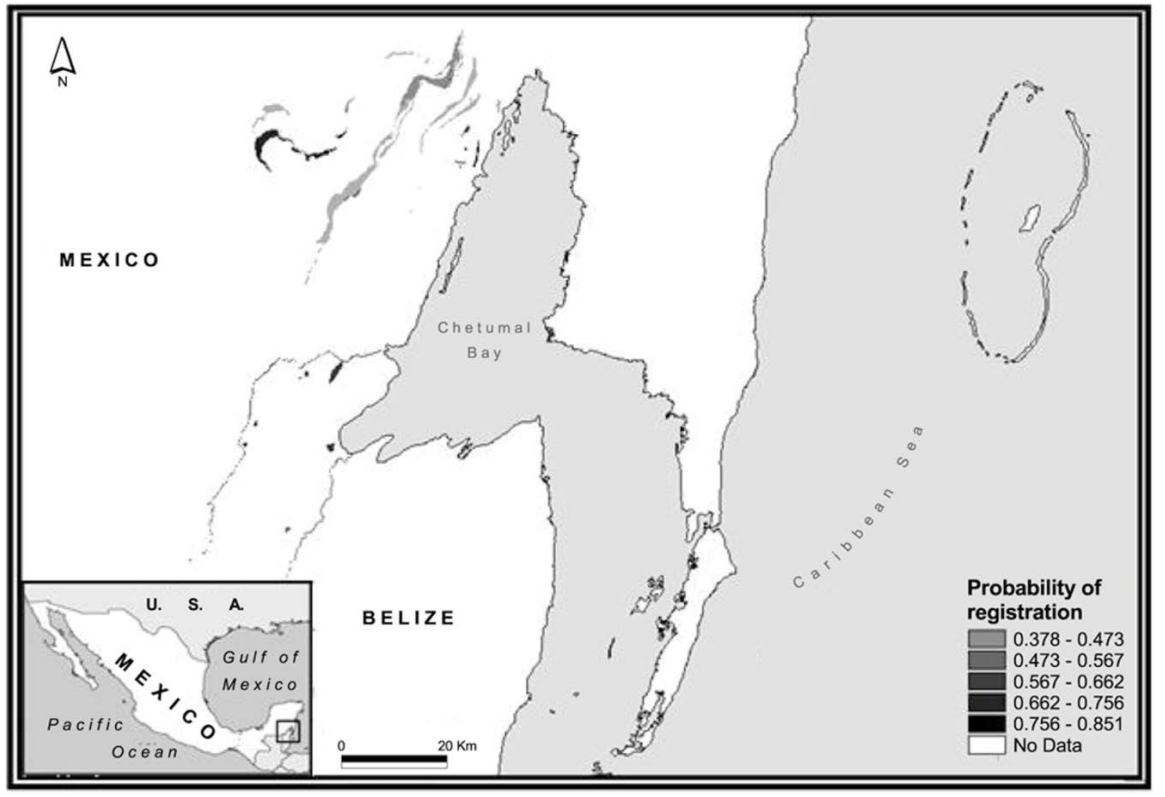

Figure 2: Potential distribution of the species in the study area, estimated using Maxent. Only values the estimated threshold by the software (0.318) are shown for the probability of occurrence of the species on a 0 to 1 scale.

The low recapture rate during our field samplings (three individuals) suggests that the Central American River Turtle population could be object of an extractive exploitation or that it is a species with a big mobility, since an individual moved up to $4 \mathrm{~km}$ in Belize, with no mention about the lapse of time for this movement [10]. In this study, the three recaptures occurred in the same site or at distances smaller than $1 \mathrm{~km}$, which is why that extraction -frequently documented in the area- might be the cause for the low recaptures $[3,16]$. The records of individuals in areas outside of the sampling sites indicate that it is necessary to do further surveys to obtain information on their movement patterns and home ranges.

Sex proportion of 2.5:1 (males: females) is slightly lower than the 3:1 reported from Montes Azules [9]; and half of what it is generally reported for other wild populations in Chiapas [39]. Probably this might be related probably to the preference of fishermen toward females [16].

Finally, we must point out that individuals captured during this study were smaller than what it has been traditionally reported for the species $[1,2,17,34,35]$. Our data only show two size classes from those proposed by Vogt \& Flores-Villela [9] in a population not heavily fished, with an almost complete lack of hatchlings or young individuals and without individuals bigger than $40 \mathrm{~cm}$. During interviews with some fishermen, adult size was mentioned to be smaller in our study area, than those fishermen have seen in other States as Tabasco [16]. The genetic differences found in this population by Gonzalez-Porter et al. [37], may be associated with adult size. This issue needs further investigation, and results may contribute to exercise conservation measures focus in this population due to its differentiation.

On the other hand, we have to consider that the low number of young individuals found, may be an artifact of the sampling technique, since we used nets with similar or bigger netting than hatchlings size, reducing the chances of their capture. The use of nets with smaller netting or free diving may compensate the paucity of hatchling in our survey.
Although there is a bigger probability to find the Central American River Turtle in habitats with a large availability of food and shelters $[24,25]$; our analyses show that from 12 variables evaluated in sites near the Chetumal Bay, only salinity stands out as a limiting factor for the species distribution. In the case of reptiles that inhabit fresh waters, salinity is recognized as a limiting factor for the colonization of estuarine waters, the lack of osmoregulation processes in some reptiles play an important role is their absence of in saline waters [40]. This may explain the absence of D. mawii in localities close to Chetumal's Bay, with relatively high salinity conditions. The species preference for fresh water is well documented and acknowledged to restrict its distribution and abundance in the zone $[2,3,17]$. The occurrence in saline zones is considered occasional or for young organisms $[8,10]$. It is unknown how they cope with salinity for short periods of time.

The distribution map resulting from modeling the ecological conditions inhabited by $D$. mawii, shows water bodies not previously considered that may shelter or sheltered the species. Information related to archeological sites, indicates the presence of the species in areas in the center and north of the Yucatan Peninsula [41,42]. In these places the turtle was used as food resource, and because of this, it is possible that it was transported as a tribute; as it is documented that the villages offered the species as offerings at ancient cities [37]. Another possibility is that its distribution was wider in the past, and has been reduced or that the turtle still might be present in water bodies not considered as part of its current distribution, as occurred in the high and inaccessible parts of the Rio Hondo and lake systems as San Felipe and Laguna Negra, where the species was not previously recorded. It is important to mention that the potential distribution map omitted water bodies where the species has been recorded. The reason for these omissions is the lack of cartographical information to the finest possible scale that reflects the real structure of its habitat. In our case, the lack of a detailed map with the salinity values and Bathymetry of the water bodies to a convenient scale prevents a higher precision in the models $[28,43]$. Detailed maps for depth, slope, bottom vegetation and dissolved oxygen, could improve the distribution and abundance modeling for the species [24,25]. 
Citation: Calderón-Mandujano RR, Hernández-Arana HA, Flores-Villela OA (2017) Distribution and Abundance of the Central American River Turtle, Dermatemys Mawii, in Southern Quintana Roo, Mexico: Implications for a Regional Conservation Strategy. J Biodivers Endanger Species 5: 198. doi: 10.4172/2332-2543.1000198

\section{Implications for conservation and management}

Recent data indicate that the Southeastern Quintana Roo must be considered as a relevant part of the distribution of $D$. mawii. Moreover, more detailed information about the biology and ecology of the species is needed before it can be considered in management and conservation plans $[3,44]$. Available data indicate that populations of D. mawii exist at relatively low thresholds due to: 1) characteristics of the species' life history, (low reproductive rate and late sexual maturity) and 2) the effect of extractive use by humans who rely on the species as a food source $[3,5,6,15]$. We recommend the establishment of a monitoring program for the populations in the zone, as well as population genetic studies, to better evaluate the regional status of this species. The recorded abundances obtained by our work, are higher than that obtained in recent years for southwest Mexico $[8,24,25,45,46]$ and offers new expectations to conduct research, conservation and develop a non-extractive approach for resource management such as ecotourism.

Our results agree with those obtained by Rainwater et al. [7] in Belize, with respect to the use for the species, although these authors worked a different basin to the north of Belize. The present study only considered the exploitation on the Mexican side of Rio Hondo, but it is clear that conservation actions should be done together between the two countries as they share responsibility for Rio Hondo and the biodiversity found in it. Actions should include coordinated legal regulations of the turtle use between the two countries and research programs promoting a better knowledge and the maintenance of the D. mawii populations in the frontier. We consider a priority establishing breeding programs in situ, Units for Management and Exploitation (known in Mexican as UMAS), monitoring programs for the knowledge and protection of the species in this zone, supported by local users, who finally know and can regulate the exploitation of the species. The places where it has been recorded or with potential for the occurrence of the species could be used to establish UMAS in semi-captivity, offering an economic alternative for local inhabitants, as well as the opportunity for research on the biology and ecology of the Central American River Turtle.

\section{Acknowledgements}

This work was conducted with the support from the following people we would like to acknowledge: Miguel Tun, Raúl Cámara, Rodrigo Pacheco and Ariane Dor who volunteered in the field work; the field guides Nacho and Yosi (Ejido Obregón Viejo), Daniel (Calderitas), Ausencio and Ricardo (La Unión), and Santos (Laguna Guerrero). Holger Weissenberger and Janneth Padilla-Saldivar kindly prepared the maps. Sophie Calmé, Norma Manríquez and Ariane Dor offered suggestions that substantially improved earlier versions of this paper. Walther Schmidt and Adam Clause performed the translation. This project was supported by a CONACYT grant (172707) to the first author, with additional funding from the Turtle Conservation Fund (TFC0809) obtained through Conservation International and with equipmen donated by IDEAWILD. Field work was authorized under a SEMARNAT/SGPA DGVS 05594/09 permit.

\section{References}

1. Rhodin AGJ, Walde AD, Horne BD, van Dick PP, Blanck T, et al. (editors.) (2011) Turtles in Trouble: The World's 25+ Most Endangered Tortoises and Freshwater Turtles-2011. Lunenburg, MA: IUCN7SSC Tortoise and Freshwater Turtle Specialist Group, Turtle Conservation Fund, Turtle Survival Alliance, Turtle Conservancy, Chelonian Research Foundation, Conservation International, Wildlife Conservation Society and San Diego Zoo.

2. Köhler G (2008) Reptiles of Central America (2nd Edn.), Offenbach, Herpeton Verlag, Germany.

3. Vogt RC, Polisar JR, Moll D, González-Porter G (2011) Dermatemys mawi Gray 1847, Central American River Turtle, Tortuga Blanca, Hickatee. 058. In: Rhodin AGJ, Walde AD, Horne BD, van Dijk PP, Blanck T, Hudson R (editors) Turtles in Trouble: The World's 25+ Most Endangered Tortoises and Freshwater Turtles -2011. Lunenburg, MA: IUCN/SSC Tortoise and Freshwater Turtle Specialist Group, Turtle Conservation Fund, Turtle Survival Alliance, Turtle Conservancy, Chelonian Research Foundation, Conservation International, Wildlife Conservation Society and San Diego Zoo.

4. Álvarez M (1982) Los Reptiles de Chiapas (3 ${ }^{\text {rd }}$ Edn.), Instituto Zoológico de Estado, Tuxtla Gutiérrez, Chiapas, México.

5. Guichard-Romero CA (2006) Situación actual de las poblaciones de Tortuga Blanca (Dermatemys mawii) en el Sureste de México. Instituto de Historia Natural y Ecología SNIB-CONABIO, México.

6. Polisar J (1995) River Turtle reproductive demography and exploitation patterns in Belize: implications for management. Vida Silv Neot 4: 10-19.

7. RainwaterTR, Pop T, Cal O, Platt S, Hudson R (2010) Catalyzing Conservation Action in Belize for Central America's Imperiled River Turtle. Turtle Alliance Report.

8. Rainwater TR, Pop T, Cal O, Garel A, Platt S, et al. (2012) A recent countrywide status survey of the critically endangered Central American River Turtle (Dematemys mawii) in Belize. Chelonian Conserv Biol 11: 97-107.

9. Vogt RC, Flores-Villela OA (1992a) Aspectos de la ecología de la Tortuga Blanca (Dermatemys mawii) en la Reserva de la Biósfera Montes Azules. In Vázquez Sánchez MA, Ramos MA (editors), Reserva de la Biósfera Montes Azules, Selva Lacandona: Investigación para su Conservación. Publicación Especial Ecosfera, Centro de Estudios para la Conservación de los Recursos Naturales, A.C., San Cristóbal de las Casas, Chiapas, México pp: 221-231.

10. Moll D (1986) The distribution, status, and level of exploitation of the freshwate turtle Dermatemys mawii, in Belize, Central America. Biol Conserv 35: 87-96.

11. Polisar J (1996) Reproductive biology of a flood-season nesting freshwater turtle of the northern Neotropics : Dermatemys mawii in Belize. Chelonian Conserv Biol 2: 13-25.

12. Polisar J, Horwich R (1994) Conservation of the large, economically importan river turtle Dermatemys mawii in Belize. Conserv Biol 8: 338-342.

13. Álvarez M, Mittermeier RA, Iverson JB (1979) River turtle in danger. Oryx 15 170-173.

14. Flores-Villela OA (1980) Reptiles de importancia económica en México. Bc Thesis Facultad de Ciencias, Universidad Nacional Autónoma de México, México.

15. Vogt RC, Flores-Villela OA (1992b) Effects of incubation temperature on sex determination in a community of neotropical freshwater turtles in Southern Mexico. Herpetologica 48: 265-270.

16. Calderón-Mandujano RR (2008) Conocimiento y uso de la Tortuga blanca (Dermatemis mawii Gray, 1847) en diez ejidos en el Sur de Quintana Roo, México. Etnobiología 6: 42-55.

17. Lee JC (1996) The amphibians and reptiles of the Yucatan Peninsula. Comstock Publishing Association. Ithaca and London.

18. Viveros-León $P$ (1996) Uso tradicional y estatus de la Tortuga Blanca de río (Dermatemys mawii) en el complejo lagunar Guerrero, Quintana Roo, México. Msc Thesis. El Colegio de la Frontera Sur, Chetumal, Quintana Roo, México.

19. INEGI (Instituto Nacional de Estadística y Geografía) (2006) Carta Hidrológica de aguas superficiales 1:1 000 000. INEGI México.

20. Carrillo L, Palacios-Hernández E, Ramírez AM, Morales-Vela JB (2009) Características Hidrometeorológicas y batimétricas. In: Espinoza-Ávalos $\mathrm{J}$ Islebe GA, Hernández.Arana HA (Eds) El sistema ecológico de la Bahía de Chetumal / Corozal: Costa Occidental del Mar Caribe, El Colegio de la Frontera Sur. Chetumal, Quintana Roo, México pp: 12-20.

21. Camarena-Luhrs T, Salazar-Vallejo S (1991) Estudios ecológicos preliminares en la Zona Sur de Quintana Roo. Centro de Investigaciones de Quintana Roo, México.

22. Rzedowski J (2006) Edición digital, Comisión Nacional para el Conocimiento y Uso de la Biodiversidad. México.

23. Pledger S, Efford M (1998) Correction of bias due to heterogeneous capture probabilities in capture-recapture studies of open populations. Biometrics 54 888-898.

24. Ureña-Arana CA (2007) Evaluación del hábitat de la Tortuga Blanca (Dermatemys mawii Gray 1847) en humedales de la Cuenca Baja del Papaloapan, Veracruz. MSc Thesis, Instituto Nacional de Ecología, AC Jalapa, Veracruz, México. 
Citation: Calderón-Mandujano RR, Hernández-Arana HA, Flores-Villela OA (2017) Distribution and Abundance of the Central American River Turtle, Dermatemys Mawii, in Southern Quintana Roo, Mexico: Implications for a Regional Conservation Strategy. J Biodivers Endanger Species 5: 198. doi: 10.4172/2332-2543.1000198

25. Zenteno-Ruiz CE, Macías EB, Bello-Guitérrez J, Ochoa-Gaona S (2010) Caracterización espacio-temporal del hábitat y presencia de Dermatemys mawii (Testudines: Dermatemydae) en la cuenca del Grijalva-Usumacinta, Tabasco, México. Rev Biol Trop 58: 1247-1260.

26. Krebs CJ (2001) Ecology: The Experimental analysis of distribution and abundance ( $5^{\text {th }}$ Edn.), Addison Wesley Longman, USA.

27. http.//www.statsoft.com/textbook

28. Phillips SJ, Dudik M, Schapire RE (2004) A Maximum Entropy Approach to Species Distribution Modelling. Proc $21^{\text {st }}$ Int Conf Machine Learning, Banff, Canada.

29. Elith J, Phillips S, Hastie T, Chee Y, Yates C, et al. (2011) A statistical explanation of Maxent for ecologists. Divers Distrib 17: 43-57.

30. Papes M, Gaubert P (2007) Modelling ecological niches from low numbers of occurrences: assessment of the conservation status of poorly known viverrids (Mammalia, Carnivora) across two continents. Divers Distrib 13: 890-902.

31. García G, Secaira F (2006) Una visión para el futuro: cartografía de las selvas mayas. Zoque y Olmeca. CI, ECOSUR, FDN, PFB, PPY, TNC, WCS, San José, Costa Rica.

32. Calderón-Mandujano R, Cedeño-Vázquez JR, Bahena-Basave H (2009) Herpetofauna: análisis y perspectivas. In: Espinoza-Ávalos J, Islebe GA, Hernández.Arana HA (editors) El sistema ecológico de la Bahía de Chetumal I Corozal: Costa Occidental del Mar Caribe, El Colegio de la Frontera Sur. Chetumal, Quintana Roo, México pp: 148-159.

33. Bahena-Basave H (1994) Los reptiles de La Unión, Sur de Quintana Roo y algunos aspectos de sus hábitos alimenticios. BSc Thesis, ENEP-Ixtacala, Universidad Nacional Autónoma de México, México.

34. Lee JC (2000) A field guide to the amphibians and reptiles of the Maya world. Cornell University Press, Ithaca and London.

35. Campbell JA (1998) Amphibians and Reptiles of Northern Guatemala, the Yucatan Peninsula and Belize. University of Oklahoma Press, Norman.

36. Böhm M, Collen B, Baillie EM, Bowles P, Canson J, et al. (2013) The conservation status of the world's reptiles. Biol Cons 157: 372-385.
37. González-Porter GP, Hailer F, Flores-Villela O, García-Anleu R, Maldonado JE (2011) Patterns of genetic diversity in the critically endangered Centra American River Turtle: human influence since the Mayan age? Conser Genet 12: $1229-1242$.

38. González-Porter GP, Maldonado JE, Flores-Villela O, Vogt RC, Janke A, et al (2013) Cryptic population structuring and the role of the Isthmus of Tehuantepec as a gene flow barrier in the critically endangered Central American River Turtle. PLoS ONE 8: e71668.

39. Lozada MN (1988) Contribución al conocimiento de la biología de la Tortuga Plana del Sureste Dermatemys mawii Gray 1847, en el Municipio de Juárez, Chiapas. Bc Thesis. Facultad de Ciencias, Universidad Nacional Autónoma de México, México.

40. Dunson WA, Mazzotti FJ (1989) Salinity as a limiting factor in the distribution of reptiles in Florida Bay: a theory for the estuarine origin of marine snakes and turtles. Bull Mar Sci 44: 229-244.

41. Götz CM (2008) Coastal and inland patterns of faunal exploitation in the prehispanic northern Maya lowlands. Quart Int 191: 154-169.

42. Götz CM (2014) La alimentación de los mayas prehispánicos vista desde la zooarqueología. An Antropol 48:167-199.

43. Philips SJ, Anderson RP, Schapire RE (2006) Maximum entropy modeling of species geographic distributions. Ecol Modell 190: 231-259.

44. CONABIO-DGVS-CONANP (2009) Estrategia Nacional para la Conservación y el Manejo Sostenible de la Tortuga Blanca (Dermatemys mawii) en México Comisión Nacional para el Conocimiento y Uso de la Biodiversidad, México.

45. Gil G (2008) Hábitos alimentarios de Dermatemys mawii Gray 1847 (Testudines: Dermatemidae) en la Reserva de la Biósfera Pantanos de Centla, Tabasco, México. BC Thesis, Facultad de Ciencias, Universidad Naciona Autónoma de México, México.

46. Rangel-Mendoza JR, Weber RM, Centeno-Ruiz CE, López-Luna MA, BarbaMacías E (2009) Hematology and serum biochemistry comparison in wild and captive Central American river turtles (Dermatemys mawii) in Tabasco, Mexico. Res Vet Sci 87: 313-318. 